\title{
Mixed ligand complexes of gold (III) with some amino acids and dithiocarbamates or dithiophosphates
}

\author{
Mikkat Zaghlool Hamdi., Ihsan Abdulghani Mustafa \\ Department of Chemistry, College of science University of Mosul, Mosul, Iraq. \\ Email address: \\ Mikkat2009@yahoo.com (M. Z. Hamdi), Ihsan_mustafa@yahoo.com (I. A. Mustafa)
}

To cite this article:

Mikkat Zaghlool Hamdi., Ihsan Abdulghani Mustafa. Mixed Ligand Complexes of Gold (III) with Some Amino Acids and Dithiocarbamates or Dithiophosphates. Science Journal of Analytical Chemistry. Vol. 1, No. 2, 2013, pp. 21-27.

doi: 10.11648/j.sjac.20130102.13

\begin{abstract}
Complexes of the type $\left[\mathrm{Au}(\mathrm{L})\left(\mathrm{L}^{-} \mathrm{orL}^{-}\right)\right] \mathrm{Cl}$ were prepared $[\mathrm{L}=$ deprotonated glycine (Gly), Alanine (Ala), Valine(Val) or Methionine (Met), $\mathrm{L}^{-}=\mathrm{N}$-Methylcyclohexyldithiocarbamate(N-MeCHdtc) or Benzyldithiocarbamate(Bzdtc) anion and $\mathrm{L}^{=}=0,0$-Dipropyldithiophosphate (DiPrdtp) or 0,0- Dibenzyldithiophosphate (DiBzdtp) anion. The prepared complexes were characterized by elemental analysis, molar conductivity, IR and UV-Vis spetra, magnatic susceptibility and $\left({ }^{1} \mathrm{H}-\mathrm{nmr}\right)$ for some of the complexes. The gold(III) complexes were all square planar with the dithiocarbamates or dithiophosphates acted as bidentate ligands coordinated through the two sulfur atoms and the aminoacid anions coordinated through $\mathrm{N}$ and $\mathrm{O}$ except for the methionine ligand which coordinate through $\mathrm{S}$ and $\mathrm{N}$ atoms.
\end{abstract}

Keywords: Amino Acid Complex, Dithiocarbamates, Dithiophosphates

\section{Introduction}

The chemistry of gold has attracted increasing attention in antitumor chemotherapy [1,2]. Complexes of gold(III) with bidentate ligands presented a number of important applications in chemotherapy, diagnostics, catalysis and surface chemistry $[3,4]$. Some gold complexes have been used as injections to reduce the pain and swelling of rheumatoid arthritis and tuberculosis [5]. Aminoacids are well known of their biological importance as structure units that build up proteins, and their common use in nutritional supplements, fertilizers and food technology [6-8]. Dithiocarbamates, dithiophosphates and their metal complexes are important compounds in many biological, industrial and agricultural aspects $[9,10]$. Mixed ligand complexes plays an important role in biological activities against pathogenic microorganism [11]. This paper report the synthesis and characterization of gold(III) mixed ligand complexes with some aminoacids (glycine, alanine, valine and methionine) and dithiocarbamates (Nmethylcyclohexyl and benzyl) or dithiophosphates (o,odipropyl and o,o-dibenzyl).

\section{Experimental}

\subsection{Materials and Methods}

Sodium salt of the dithiocarbamates( Nmethylcyclohexyl) and (benzyl ) or dithiophosphates (o,oDipropyl) and (o,o-Dibenzyl) were prepared as cited in the literature [12,13], Auric acid, glycine, alanine, valine , methionine, N-methylcyclohexyl amine, benzylamine, carbon disulfide, propyl alcohol, benzyl alcohol, phosphorus pentasulfide and sodium hydroxide were either Aldrich, BDH or Fluka products.Organic solvents (dimethylformamide and diethylether) were reagent grade chemicals.

Preparation of complexes

Preparation of $[\mathrm{Au}(\mathrm{N}-\mathrm{MeCHdtc})(\mathrm{Gly})] \mathrm{Cl}$

A solution of sodium aurrate $\mathrm{Na}\left(\mathrm{AuCl}_{4}\right)$ (prepared by adding aqueous solution of $\mathrm{NaHCO}_{3}$ to a solution of $\mathrm{HAuCl}_{4} \cdot 4 \mathrm{H}_{2} \mathrm{O}(0.0005 \mathrm{~mol}, 0.206 \mathrm{gm})$ in $\left(10 \mathrm{~cm}^{3}\right)$ water to $\mathrm{PH}$ 7.0) was added with stirring to a solution mixture of $\mathrm{Na} \mathrm{N}-\mathrm{MeCHdtc}(0.0005 \mathrm{~mol}, 0.105 \mathrm{gm})$ in $\left(10 \mathrm{~cm}^{3}\right)$ water and aqueous solution of sodiumglycinate, NaGly, (prepared by dissolving $(0.0005 \mathrm{~mol}, 0.038 \mathrm{gm})$ of glycine in $\left(5 \mathrm{~cm}^{3}\right)$ water followed by the addition of aqueous solution of $\mathrm{NaOH}$ to $\mathrm{PH}$ 7.5). The resulting precipitate was filtered, washed several times with water and dried in air.

The following complexes of Ala, Val and Met with NMeCHdtc and complexes of the four aminoacds with Bzdtc in addition to their corresponding complexes of DiPrdtp and DiBzdtp were prepared using the same method with the 
same number of moles $(0.0005 \mathrm{~mol})$ but using the appropriate weight for each:

[Au (N-MeCHdtc) (Ala) $\mathrm{Cl}(0.0445 \mathrm{gm})$ of alanine $[\mathrm{Au}$ (NMeCHdtc) (Val)] $\mathrm{Cl}(0.117 \mathrm{gm})$ of valine [Au $(\mathrm{N}-$ $\mathrm{MeCHdtc})$ (Met)] $\mathrm{Cl}$ (0.149gm) of methionine, [Au (Bzdtc) (L)] $\mathrm{Cl}$ (0.102gm of NaBzdtc), [Au (L) (DiPrdtp)] $\mathrm{Cl}$ (0.118gm of $\mathrm{NaDiPrdtc}$ and [Au(L) (DiBzdtp)] $\mathrm{Cl}(0.166 \mathrm{gm})$ of NaDiBzdtp.

\section{Physical Measurements}

Elemental analysis of carbon, hydrogen, nitrogen, and sulfur were done using Euro Vactor Model EA 3000 A (Italy) ( Al al bait University, Jorden), IR spectra were recorded on Fourier-Transform (FT.IR) Spectrophotometer, Tensor27Co.Brucker 2003 at a range $\left(400-4000 \mathrm{~cm}^{-1}\right)$ using $\mathrm{KBr}$ discs, Electronic spectra were recorded on a U.V-Vis. Spectrophotometer (Shimadzu, UV-1650PCSpectrophotomete using DMF as a solvent at room temperature for the dithiocarbamate complexes (no.1-8) and at $\sim 40^{\circ} \mathrm{C}$ for the dithiophosphate complexes (no.9-16) with partial dissolution. Magnetic susceptibility have been measured by Bruker B.M.6. using the Faraday method, Conductivity measurements for the dithiocarbamate complexes have been carried out using DMF as a solvent $\left(10^{-3} \mathrm{M}\right)$ at room temperature with conductivity Meter Model PCM3Jenway, conductivity of the dithiophosphate complexes were measured in the solid state using 3 Pope Cell. Proton nuclear magnetic resonance $\left({ }^{1} \mathrm{H}-\mathrm{nmr}\right)$ for some of the dithiocarbamate complexes were measured using DMSO $-\mathrm{d}_{6}$ as a solvent at $\left(25^{\circ} \mathrm{c}\right)$ with BRUKER $300 \mathrm{MHZ}$ ( Al al bait University, Jorden), Melting and Decomposition points were done using Electriothermal 9300 Engineering LTD.

\section{Result and Discussion}

The reaction of sodium aurrate, sodium salt of amino acid and sodium salt of dithiocarbamate or dithiophosphate ligands may be reported by the following equation

$$
\mathrm{NaAuCl}_{4}+\mathrm{NaL}+\mathrm{Na}\left(\mathrm{L}^{-} \text {orL }^{=}\right) \longrightarrow\left[\mathrm{Au}(\mathrm{L})\left(\mathrm{L}^{-} \operatorname{orL}^{=}\right)\right] \mathrm{Cl}+3 \mathrm{NaCl}
$$

Elemental analyses (Table1) revealed that the complexes have the compositions [Au (L) $(\mathrm{L}-\mathrm{ArL}=)$ ] $\mathrm{Cl}$. Molar conductivity of the dithiocarbamate complexes were measured in dimetylformamide (10-3M) solvent indicate that theses complexes are 1:1 electrolyte [14]. The corresponding dithiophosphate complexes $[\mathrm{Au}$ (L) (DiPrdtp)] $\mathrm{Cl}$ and [Au (L) (DiBzdtp)] $\mathrm{Cl}$, are partially soluble in warm $\operatorname{DMF}(40 \mathrm{oc})$ but insoluble in THF, cyanomethane, benzene, dichloromethane, chloroform, DMSO, DMF+DMSO mixture and ethanol. Accordingly, the conductivity of the dithiophosphate, were measured in the solid state and the results obtain, indicate their 1:1 electrolytic nature Table(2) give some physical properties in addition to elemental analysis for the prepared complexes. The Magnetic moments of the complexes (Table 2) calculated from the corrected magnetic susceptibilities determined at room temperature indicate the diamagnetic nature, as expected for low spin $\mathrm{d} 8$ complexes, suggesting square planar geometries for the gold(III) complexes[15].

The electronic spectra for diamagnetic gold(III) complexes are similar to their iso electronic counter part platinum(II) complexes expected to possess three spin allowed transitions in the field of square planar geometry represented by

$$
\begin{aligned}
{\left[{ }^{1} \mathrm{~A}_{1} \mathrm{~g} \longrightarrow{ }^{1} \mathrm{~A}_{2} \mathrm{~g}\right], \mathrm{b}_{2} \mathrm{~g}(\mathrm{dxy}) \longrightarrow \mathrm{b}_{1} \mathrm{~g}\left(\mathrm{dx}^{2}-\mathrm{y}^{2}\right)\left(v_{1}\right) } \\
\left.{ }^{1} \mathrm{~A}_{1} \mathrm{~g} \longrightarrow{ }^{1} \mathrm{~B}_{1} \mathrm{~g}\right], \mathrm{a}_{2} \mathrm{~g}(\mathrm{dxy}) \longrightarrow \mathrm{b}_{1} \mathrm{~g}\left(\mathrm{dx}^{2}-\mathrm{y}^{2}\right)\left(v_{2}\right) \\
{\left[{ }^{1} \mathrm{~A}_{1} \mathrm{~g} \longrightarrow{ }^{1} \mathrm{Eg}\right], \mathrm{e}_{2} \mathrm{~g}(\mathrm{dxy}) \longrightarrow \mathrm{b}_{1} \mathrm{~g}\left(\mathrm{dx}^{2}-\mathrm{y}^{2}\right)\left(v_{3}\right) }
\end{aligned}
$$

The electronic spectra of the prepared gold(III) complexes gave three absorption bands at the range $\left(21230-21800 \mathrm{~cm}^{-1}\right), \quad\left(24700-26246 \mathrm{~cm}^{-1}\right)$ and (28248$\left.30120 \mathrm{~cm}^{-1}\right)$. These bands $C$ an be assigned to ${ }^{1} \mathrm{~A}_{1} \mathrm{~g}{ }^{1} \mathrm{~A}_{2} \mathrm{~g}\left(v_{1}\right)$,

${ }^{1} \mathrm{~A}_{1} \longrightarrow{ }^{1} \mathrm{~B}_{1} \mathrm{~g}\left(\mathrm{v}_{2}\right)$ and ${ }^{1} \mathrm{~A}_{1} \mathrm{~g} \longrightarrow{ }^{1} \mathrm{Eg}\left(v_{3}\right)$ transition respectively, (Table2), the position of these bands are in agreement with low-spin square planar geometry for gold(III) complexes [16]. Bands at values higher than $30000 \mathrm{~cm}^{-1}$ were assigned to charge transfer.

The significant ir spectra data of the ligands and their gold(III) complexes with assignments are listed in (Table3). The $v(\mathrm{C}-\mathrm{S})$ band in the ir spectra of the two dithiocarbamate ligands shown at 957 and $990 \mathrm{~cm}^{-1}$ shifted to lower region $\left(\mathrm{cm}^{-1}\right)$ in the ir spectra of their complexes (complex no.1-8). The shift together with the presence of one $v(\mathrm{C}-\mathrm{S})$ band only suggest the bidentate coordination of the dithiocarbamate in their complexes. The $v(\mathrm{C}-\mathrm{N})$ band position which is usually taken as a measure of the thioureide form to the structure of dithiocarbamate compounds[17], appeared in the ir spectra of the two dithiocarbamate ligands (N-MeCHdtc and Bzdtc) at 1454 and $1469 \mathrm{~cm}^{-1}$, respectively. These positions were shifted to higher frequency values $\left(1487-1508 \mathrm{~cm}^{-1}\right)$ on complex formation. It has been proved that this band undergoes blue shift, when the dithiocarbamate act as bidentate chelating ligand $[18,19]$. These observation tend to further support the bidentate nature of the dithiocarbamates in their gold(III) complexes.

The free dithiophosphate ligands exhibit $v_{\mathrm{s}}(\mathrm{P}-\mathrm{S})$ band appeared at 538 and $563 \mathrm{~cm}^{-1}$ (Table3). These bands were shifted to lower frequencies upon complex formation (517$\left.558 \mathrm{~cm}^{-1}\right)$. On the other hand the $v_{\text {as }}(\mathrm{P}-\mathrm{S})$ ir bands for the two dithiophosphate ligands located at 617 and $619 \mathrm{~cm}^{-1}$ were shifted to higher frequencies in the ange $622-644 \mathrm{~cm}^{-1}$ upon the formation of gold (III) complexes. These observation indicate the bidentate coordination of the dithiophosphate ligands in their complexes [20,21]

The $v(\mathrm{P}-\mathrm{O})$ band appear at $985,993 \mathrm{~cm}^{-1}$ in the free dithiophosphate ligands, were shifted to lower frequencies $\left(958-977 \mathrm{~cm}^{-1}\right)$ upon complex formation. 
The observed shift of $v(\mathrm{P}-\mathrm{O})$ support the bonding of the two sulfur atoms to gold(III) because the observed shift is an indication of electron drainage form theP-O towards $\mathrm{P}-\mathrm{S}$ [22]

Table 1. Some physical properties and elemental analysis of the prepared complexes

\begin{tabular}{|c|c|c|c|c|c|c|c|c|}
\hline \multirow{2}{*}{ Complex No. } & \multirow{2}{*}{ Complex formula } & \multirow{2}{*}{ Colour } & \multirow{2}{*}{$\begin{array}{c}\left.\text { M.P(C } C^{0}\right) \\
\text { Dec.p }\end{array}$} & \multirow{2}{*}{ Yield (\%) } & \multicolumn{4}{|c|}{ Elemental analysis, found/(calc.) } \\
\hline & & & & & $\mathrm{C} \%$ & H\% & N\% & $\mathrm{S} \%$ \\
\hline 1 & {$[\mathrm{Au}(\mathrm{N}-\mathrm{MeCHdtc})(\mathrm{Gly})] \mathrm{Cl}$} & Yellow & $120^{*}$ & 81 & $\begin{array}{c}24.68 \\
(24.27)\end{array}$ & $\begin{array}{c}4.02 \\
(3.66)\end{array}$ & $\begin{array}{c}6.01 \\
(5.66)\end{array}$ & $\begin{array}{c}13.60 \\
(12.95)\end{array}$ \\
\hline 2 & [Au (N-MeCHdtc)(Ala)]Cl & Brown & $142 *$ & 79 & $\begin{array}{c}27.05 \\
(25.96)\end{array}$ & $\begin{array}{c}4.15 \\
(3.96)\end{array}$ & $\begin{array}{c}5.86 \\
(5.50)\end{array}$ & $\begin{array}{c}13.22 \\
(12.60)\end{array}$ \\
\hline 3 & {$[\mathrm{Au}(\mathrm{N}-\mathrm{MeCHdtc})(\mathrm{Val})] \mathrm{Cl}$} & Brown & $104 *$ & 88 & $\begin{array}{c}28.69 \\
(29.08)\end{array}$ & $\begin{array}{c}3.91 \\
(4.50)\end{array}$ & $\begin{array}{c}5.42 \\
(5.21)\end{array}$ & $\begin{array}{c}12.32 \\
(11.94)\end{array}$ \\
\hline 4 & [Au (N-MeCHdtc)(Met)]Cl & Deep-brown & $132 *$ & 83 & $\begin{array}{c}27.96 \\
(27.44)\end{array}$ & $\begin{array}{c}4.63 \\
(4.25)\end{array}$ & $\begin{array}{c}5.12 \\
(4.92)\end{array}$ & $\begin{array}{c}17.36 \\
(16.90)\end{array}$ \\
\hline 5 & {$[\mathrm{Au}(\mathrm{Bzdtc})(\mathrm{Gly})] \mathrm{Cl}$} & Reddish- brown & $167 *$ & 79 & $\begin{array}{c}24.78 \\
(24.57)\end{array}$ & $\begin{array}{c}2.61 \\
(2.47)\end{array}$ & $\begin{array}{c}6.47 \\
(5.73)\end{array}$ & $\begin{array}{c}13.30 \\
(13.11)\end{array}$ \\
\hline 6 & [ Au (Bzdtc)(Ala)Cl & Brown & $185^{*}$ & 77 & $\begin{array}{c}26.48 \\
(26.27)\end{array}$ & $\begin{array}{c}3.12 \\
(2.80)\end{array}$ & $\begin{array}{c}5.98 \\
(5.57)\end{array}$ & $\begin{array}{c}12.97 \\
(12.75)\end{array}$ \\
\hline 7 & {$[\mathrm{Au}(\mathrm{Bzdtc})(\mathrm{Val})] \mathrm{Cl}$} & Brown & $166^{*}$ & 68 & $\begin{array}{c}30.12 \\
(29.41)\end{array}$ & $\begin{array}{c}3.15 \\
(3.41)\end{array}$ & $\begin{array}{c}5.68 \\
(5.27)\end{array}$ & $\begin{array}{c}12.32 \\
(12.07)\end{array}$ \\
\hline 8 & {$[\mathrm{Au}(\mathrm{Bzdtc})(\mathrm{Met})] \mathrm{Cl}$} & Light- brown & $154^{*}$ & 72 & $\begin{array}{c}28.12 \\
(27.73)\end{array}$ & $\begin{array}{c}3.68 \\
(3.22)\end{array}$ & $\begin{array}{c}5.36 \\
(4.97)\end{array}$ & $\begin{array}{c}17.36 \\
(17.08)\end{array}$ \\
\hline 9 & [Au (DiPrdtp)(Gly)]Cl & Brownish black & $>300$ & 63 & $\begin{array}{c}17.24 \\
(18.48)\end{array}$ & $\begin{array}{c}3.15 \\
(3.49)\end{array}$ & $\begin{array}{c}2.78 \\
(2.69)\end{array}$ & $\begin{array}{c}12.35 \\
(12.33)\end{array}$ \\
\hline 10 & {$[\mathrm{Au}(\mathrm{DiPrdtp})(\mathrm{Ala})] \mathrm{Cl}$} & Brownish black & $>300$ & 75 & $\begin{array}{c}20.68 \\
(20.25)\end{array}$ & $\begin{array}{c}3.48 \\
(3.77)\end{array}$ & $\begin{array}{c}3.12 \\
(2.62)\end{array}$ & $\begin{array}{c}12.36 \\
(12.01)\end{array}$ \\
\hline 11 & {$[\mathrm{Au}(\mathrm{DiPrdtp})(\mathrm{Val})] \mathrm{Cl}$} & Deep-brown & $>300$ & 69 & $\begin{array}{c}23.75 \\
(23.51)\end{array}$ & $\begin{array}{c}4.01 \\
(4.30)\end{array}$ & $\begin{array}{c}2.98 \\
(2.49)\end{array}$ & $\begin{array}{c}11.36 \\
(11.41)\end{array}$ \\
\hline 12 & [ Au (DiPrdtp)(Met)]Cl & Brownish black & $>300$ & 82 & $\begin{array}{c}22.45 \\
(22.24)\end{array}$ & $\begin{array}{c}4.13 \\
(4.07)\end{array}$ & $\begin{array}{c}3.12 \\
(2.35)\end{array}$ & $\begin{array}{c}17.05 \\
(16.19)\end{array}$ \\
\hline 13 & [Au (DiBzdtp)(Gly)]Cl & Brown & $>300$ & 63 & $\begin{array}{c}31.12 \\
(31.20)\end{array}$ & $\begin{array}{c}3.15 \\
(2.94)\end{array}$ & $\begin{array}{c}2.12 \\
(2.27)\end{array}$ & $\begin{array}{c}10.35 \\
(10.41)\end{array}$ \\
\hline 14 & {$[\mathrm{Au}(\mathrm{DiBzdtp})(\mathrm{Ala})] \mathrm{Cl}$} & Brownish black & $>300$ & 65 & $\begin{array}{c}32.75 \\
(32.41)\end{array}$ & $\begin{array}{c}3.53 \\
(3.20)\end{array}$ & $\begin{array}{l}2.682 \\
(2.22)\end{array}$ & $\begin{array}{c}10.36 \\
(10.17)\end{array}$ \\
\hline 15 & {$[\mathrm{Au}(\mathrm{DiBzdtp})(\mathrm{Val})] \mathrm{Cl}$} & Brownish black & $>300$ & 77 & $\begin{array}{c}33.79 \\
(34.68)\end{array}$ & $\begin{array}{c}3.78 \\
(3.67)\end{array}$ & $\begin{array}{c}2.87 \\
(2.12)\end{array}$ & $\begin{array}{l}10.24 \\
(9.74)\end{array}$ \\
\hline 16 & {$[\mathrm{Au}(\mathrm{DiBzdtp})(\mathrm{Met})] \mathrm{Cl}$} & Brownish black & $>300$ & 82 & $\begin{array}{c}33.42 \\
(33.07)\end{array}$ & $\begin{array}{c}3.62 \\
(3.50) \\
\end{array}$ & $\begin{array}{c}2.31 \\
(2.03) \\
\end{array}$ & $\begin{array}{r}14.36 \\
(13.93) \\
\end{array}$ \\
\hline
\end{tabular}

Table 2. Electronic spectra of the ternary Ni(II) complexes $\left(\mathrm{cm}^{-1}\right), \mu$ eff (B.M.)and Molar Conductance $\left(\mathrm{cm}^{2} \mathrm{ohm}^{-1} \mathrm{~mol}^{-1}\right)$

\begin{tabular}{|c|c|c|c|c|c|c|}
\hline Complex no. & ${ }^{1} A_{1} g \longrightarrow{ }^{1} A_{2} g$ & ${ }^{1} A_{1} g \longrightarrow{ }^{1} B_{1} g$ & ${ }^{1} \mathrm{~A}_{1} \mathrm{~g} \longrightarrow{ }^{1} \mathrm{Eg}$ & C.T & $\mu$ eff B.M. & $\begin{array}{l}\text { Molar Conductance } \\
\left(\mathrm{cm}^{2} \mathrm{ohm}^{-1} \mathrm{~mol}^{-1}\right)\end{array}$ \\
\hline 1 & 21505 & 25000 & 29411 & 31250 & dia & 76.9 \\
\hline 2 & 21500 & 24700 & 29585 & 32051 & dia & 88.7 \\
\hline 3 & ---- & 25641 & 29585 & 32894 & dia & 69.8 \\
\hline 4 & 21231 & 25125 & 28248 & 32894 & dia & 85.8 \\
\hline 5 & 21230 & ---- & 30120 & 39370 & dia & 80.7 \\
\hline 6 & ---- & 26246 & ---- & 30864 & dia & 69.5 \\
\hline 7 & --- & 25840 & 28467 & 31055 & dia & 83.5 \\
\hline 8 & 21800 & 25445 & 29411 & 33112 & dia & 87.4 \\
\hline 9 & 21765 & ---- & 28769 & 33456 & dia & $3.21 \times 10^{-6}$ \\
\hline 10 & 21456 & 25367 & ---- & 37854 & dia & $4.02 \times 10^{-6}$ \\
\hline 11 & ---- & ---- & 29445 & 35099 & dia & $2.32 \times 10^{-7}$ \\
\hline 12 & 21786 & 26143 & 28564 & 36543 & dia & $2.01 \times 10^{-6}$ \\
\hline 13 & 21765 & ---- & 28760 & 32789 & dia & $2.45 \times 10^{-6}$ \\
\hline 14 & ---- & 24896 & --- & 34679 & dia & $1.42 \times 10^{-7}$ \\
\hline 15 & 21657 & ---- & 28954 & 33476 & dia & $1.82 \times 10^{-7}$ \\
\hline 16 & ---- & 24987 & ---- & 37896 & dia & $4.21 \times 10^{-6}$ \\
\hline
\end{tabular}


Table 3. Selected IR bands of the ligands and complexes $\left(\mathrm{cm}^{-1}\right)$

\begin{tabular}{|c|c|c|c|c|c|c|c|c|c|c|c|c|}
\hline \multirow{2}{*}{ No. } & \multirow{2}{*}{$\mathbf{v}\left(\mathrm{NH}_{2}\right)$} & \multicolumn{2}{|c|}{$v\left(\mathrm{COO}^{-}\right)$} & \multirow{2}{*}{$\Delta v($ COO $)$} & \multirow{2}{*}{$\mathbf{v}(\mathrm{C}-\mathrm{N})$} & \multirow{2}{*}{$v(C-S)$} & \multirow{2}{*}{ v(C-SMe) } & \multicolumn{2}{|c|}{$v(P-S)$} & \multirow{2}{*}{$v(P-O)$} & \multirow{2}{*}{$\mathbf{v}(\mathrm{M}-\mathrm{O})$} & \multirow{2}{*}{$\mathbf{v}(\mathbf{M}-\mathbf{N})$} \\
\hline & & $v_{\text {as }}\left(\mathrm{COO}^{-}\right)$ & $v_{s}(C O O)$ & & & & & $\mathbf{v}_{\text {as }}(\mathbf{P}-\mathbf{S})$ & $v_{s}(P-S)$ & & & \\
\hline NaN-MeCHdtc & ---- & ---- & ---- & ---- & 1469 & 990 & ---- & ---- & ---- & ---- & ---- & ---- \\
\hline NaBzdtc & ---- & ---- & ---- & ---- & 1454 & 957 & ---- & ---- & ---- & ---- & ---- & ---- \\
\hline NaDiPrdp & ---- & ---- & ---- & ---- & ---- & & --- & 619 & 538 & 993 & ---- & ---- \\
\hline NadiBzdp & ---- & ---- & ---- & ---- & ---- & & ---- & 617 & 563 & 985 & ---- & ---- \\
\hline Gly & 3164 & 1615 & 1457 & ---- & ---- & & ---- & ---- & ---- & ---- & ---- & ---- \\
\hline L-Ala & 3082 & 1597 & 1413 & ---- & ---- & & ---- & ---- & ---- & ---- & ---- & ---- \\
\hline L-Val & 3080 & 1590 & 1410 & ---- & ---- & & ---- & ---- & ---- & ---- & ---- & ---- \\
\hline L-Met & 2956 & 1616 & 1408 & ---- & ---- & & 1316 & ---- & ---- & ---- & ---- & ---- \\
\hline 1 & 3232 & 1633 & 1396 & 237 & 1483 & 978 & ---- & ---- & ---- & ---- & 569 & 466 \\
\hline 2 & 3115 & 1636 & 1388 & 248 & 1498 & 964 & ---- & ---- & ---- & ---- & 576 & 490 \\
\hline 4 & 3112 & 1614 & 1410 & 204 & 1492 & 966 & 1338 & ---- & ---- & ---- & ---- & 484 \\
\hline 5 & 3225 & 1628 & 1398 & 230 & 1476 & 947 & ---- & ---- & ---- & ---- & 570 & 488 \\
\hline 6 & 3090 & 1637 & 1385 & 252 & 1485 & 938 & ---- & ---- & ---- & ---- & 569 & 467 \\
\hline 7 & 3100 & 1625 & 1371 & 254 & 1488 & 944 & ---- & ---- & ---- & ---- & 577 & 498 \\
\hline 8 & 2998 & 1608 & 1406 & 202 & 1479 & 938 & 1335 & ---- & ---- & ---- & ---- & 492 \\
\hline 9 & 3232 & 1633 & 1397 & 236 & ---- & ---- & ---- & 624 & 527 & 977 & 576 & 478 \\
\hline 10 & 3100 & 1639 & 1387 & 252 & ---- & ---- & ---- & 640 & 525 & 972 & 574 & 466 \\
\hline 11 & 3115 & 1644 & 1380 & 264 & ---- & ---- & ---- & 637 & 523 & 978 & 565 & 487 \\
\hline 12 & 3108 & 1614 & 1412 & 202 & ---- & ---- & 1332 & 632 & 533 & 975 & ---- & 490 \\
\hline 13 & 3234 & 1628 & 1395 & 233 & ---- & ---- & ---- & 628 & 549 & 973 & 563 & 492 \\
\hline 14 & 3111 & 1636 & 1382 & 254 & ---- & ---- & ---- & 637 & 557 & 965 & 572 & 476 \\
\hline 16 & 2996 & 1615 & 1412 & 203 & ---- & ---- & 1337 & 632 & 548 & 967 & ---- & 488 \\
\hline
\end{tabular}

Table 4. 1H-NMR spectral data for some complexes

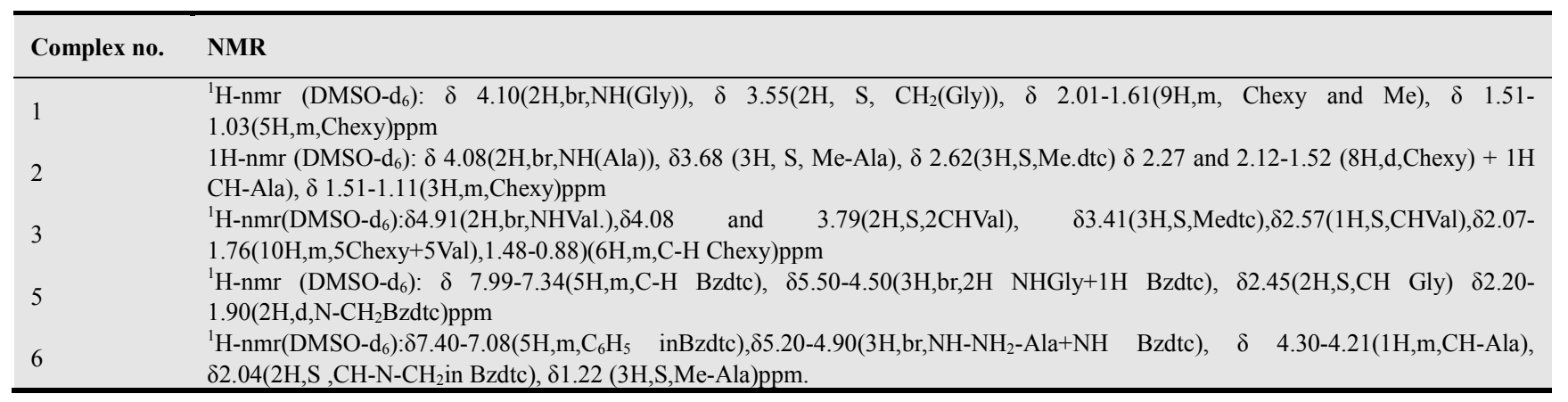

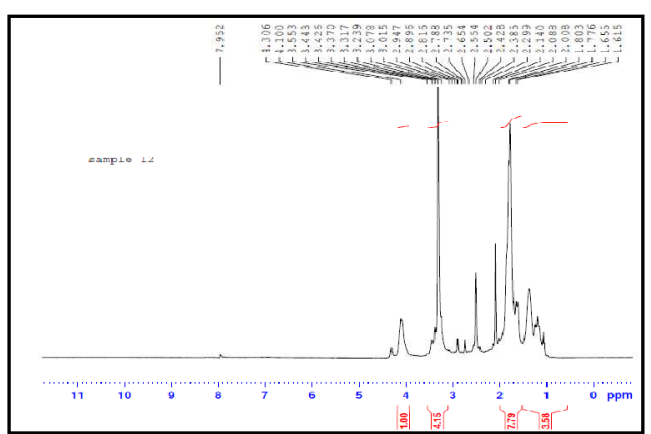

Fig 1. $\left.{ }^{1} \mathrm{H}-\mathrm{NMR}\right)$ spectrum of complex $[\mathrm{Au}(\mathrm{N}-\mathrm{MeCHdtc})(\mathrm{Gly})]^{+} \mathrm{Cl}$

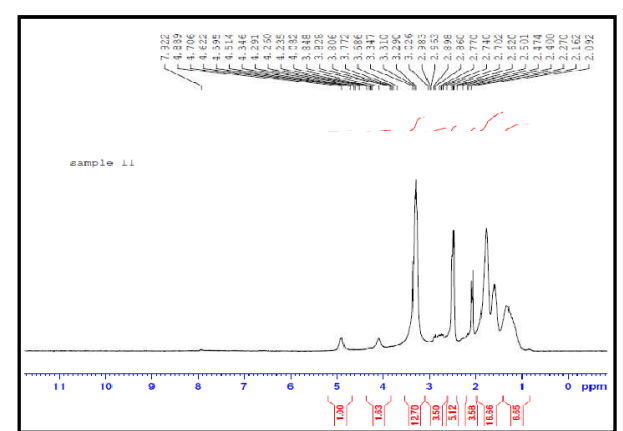

Fig 2. $\left.{ }^{l} \mathrm{H}-\mathrm{NMR}\right)$ spectrum of complex $[\mathrm{Au}(\mathrm{N}-\mathrm{MeCHdtc})(\mathrm{Ala})]^{+} \mathrm{Cl}$ 


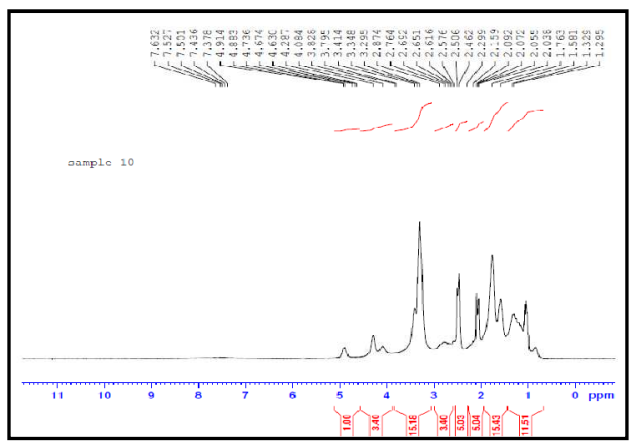

Fig 3. $\left.{ }^{l} \mathrm{H}-\mathrm{NMR}\right)$ spectrum of complex $[\mathrm{Au}(\mathrm{N}-\mathrm{MeCHdtc})(\mathrm{Val})]^{+} \mathrm{Cl}$

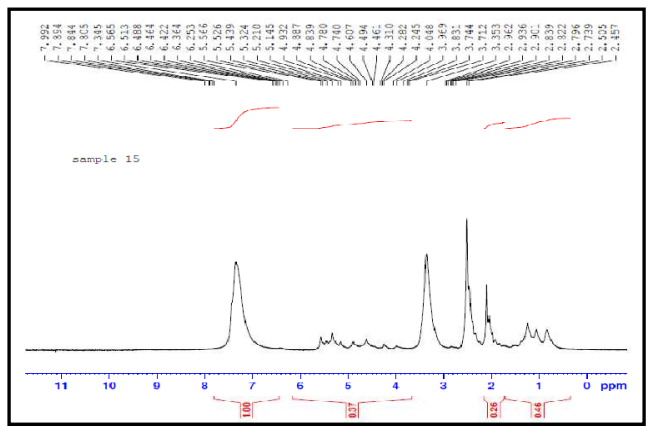

Fig 4. $\left.{ }^{l} \mathrm{H}-\mathrm{NMR}\right)$ spectrum of complex $[\mathrm{Au}(\mathrm{Bzdtc})(\mathrm{Gly})]^{+} \mathrm{Cl}$

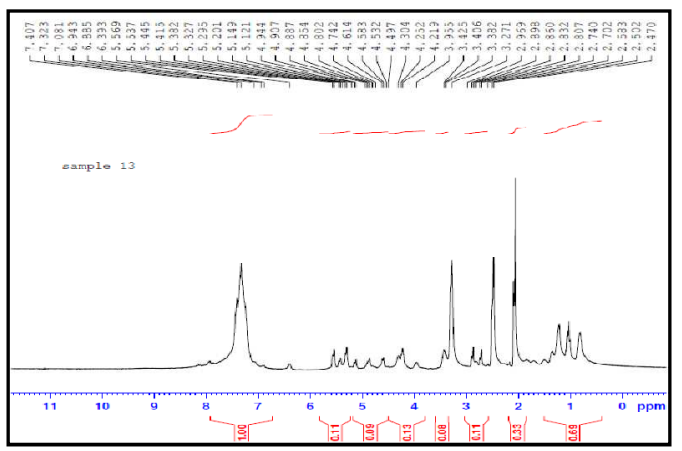

Fig 5. ${ }^{l} \mathrm{H}$-NMR) spectrum of complex $[\mathrm{Au}(\mathrm{Bz} d \mathrm{tc})(\mathrm{Ala})]^{+} \mathrm{Cl}$

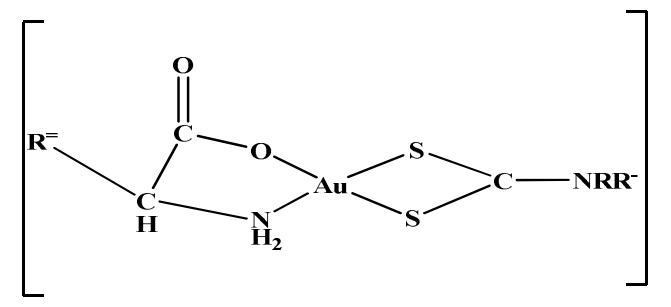

a. $\left(\mathrm{R}=\mathrm{H}\right.$ when $\mathrm{R}^{-}=$benzyl, $\mathrm{R}=\mathrm{CH}_{3}$ when $\mathrm{R}^{-}=$cyclohexyl) $\mathrm{R}^{=}=-\mathrm{H}$ (Gly), $\mathrm{CH}_{3}(\mathrm{Ala}),-\left(\mathrm{CH}\left(\mathrm{CH}_{3}\right)_{2}(\mathrm{Val})\right.$.Complex no. 1-3, 5-7

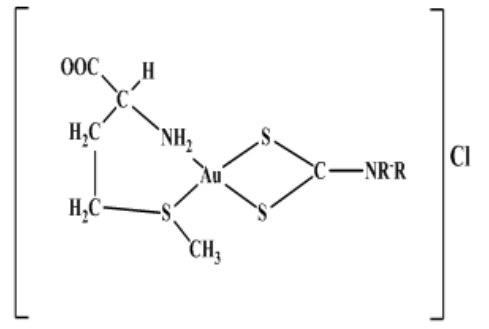

b. R,R-, as defined in Fig ( 6a.) Complex no.4,8<smiles></smiles>

c. $\mathrm{R}=$ propyl or benzyl $\mathrm{R}==$ as defined in Fig (6 a.) Complexes no.9$11,13-15$

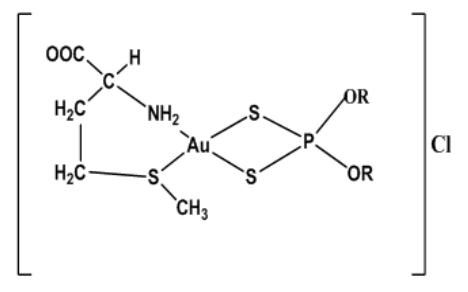

d. $\mathrm{R}=$ propyl or benzyl Complex no.12,16

Fig 6. Proposed structures for the complexes $\left[A u(L)\left(L^{-} \circ L^{=}\right)\right] C l$

The values of $v_{\mathrm{as}}\left(\mathrm{COO}^{-}\right)$and $v_{\mathrm{s}}\left(\mathrm{COO}^{-}\right)$for the aminoacid ligands are given in (Table3). The corresponding values for the gold(III) complexes indicate that the $v_{\mathrm{s}}\left(\mathrm{COO}^{-}\right)$values were shifted to lower wave numbers while the $v_{\text {as }}\left(\mathrm{COO}^{-}\right)$ frequencies were shifted to higher wave numbers[expect for the methionine complexes (no.4,8,12 and 16)]. The values of $\Delta\left[v_{\mathrm{as}}\left(\mathrm{COO}^{-}\right)-v_{\mathrm{s}}\left(\mathrm{COO}^{-}\right)\right]$for the complexes are $\left(230-272 \mathrm{~cm}^{-1}\right)$ indicate the involvement of the carboxylate anion in bonding as monodentate ligand. The values of $\Delta\left[v_{\mathrm{as}}\left(\mathrm{COO}^{-}\right)-v_{\mathrm{s}}\left(\mathrm{COO}^{-}\right)\right]$for the methionine complexes were $\left(202-204 \mathrm{~cm}^{-1}\right)$ suggesting that the carboxylate is not involved in bonding[23].

The N-H vibration observed at $\left(2956-3164 \mathrm{~cm}^{-1}\right)$ in the free aminoacids were shifted to higher wave numbers $\left(2996-3234 \mathrm{~cm}^{-1}\right)$ in the ir spectra of the complexes suggesting coordination of the amino group [24]. The $v(\mathrm{C}$ $\mathrm{S})$ in the methionine ligand appears at $1316 \mathrm{~cm}^{-1}$ were shifted to higher number $\left(1335-1338 \mathrm{~cm}^{-1}\right)$ on complex formation (complex no.4,8,12 and 16), indicating the participation of methionine sulfur in bonding[25].

The ir spectra of the complexes showed the appearance of non ligand bands observed at $\left(466-498 \mathrm{~cm}^{-1}\right)$ which were assigned to $v(\mathrm{Au}-\mathrm{N})$. The appearance of bands at (565$\left.576 \mathrm{~cm}^{-1}\right)$ in the ir spectra of the complexes, with the exception of (complexes no. 4,8,12 and 16), were assigned to $v(\mathrm{Au}-\mathrm{O})$.

Proton $\mathrm{nmr}\left({ }^{1} \mathrm{H}-\mathrm{nmr}\right)$ were recorded for five of the dithiocarbamate complexes using DMSO- $\mathrm{d}_{6}$ as solvent. The insolubility of the prepared dithiophosphate complexes in DMSO and other solvents limited the choice to samples of the dithiocarbamate complexes only. The results obtained from ${ }^{1} \mathrm{H}$-nmr spectra are given in (Table4).

\section{Conclusion}

Mixed ligand complexes of gold(III) with four aminoacids (Gly, Ala, Val and Methionine ) and two dithiocarbamates (N-MeCHdtc and Bzdtc) or two 
dithiophosphates (DiPrdtp and DiBzdtp) were successfully prepared by simple mixing of a queous solution of the three components. The results were square planar complexes of $\mathrm{Au}$ (III) with the dithiocarbamate and dithiophosphate ligands behaved as bidentate coordinated through the two sulfur atoms. The aminoacid anions coordinated through the nitrogen atom of the amino group in all complexes and through the oxygen of the carboxylate group with the exception of the methionine complexes (no.4, 8, 12 and 16) where the sulfur atom replaces the carboxylate oxygen. Similar results were reported for the isostructural platinum(II) complexes with sulfur containing aminoacids [26]. Apparently the square planar preference for gold(III) might be the motive in which case the choice of using $\mathrm{N}$ and $\mathrm{S}$ binding sites are preferred regardless of the negative charge an oxygen.

The dithiophosphate complexes are insoluble in common polar and non polar solvents such as THF, dichloromethane, ethanol, DMSO, cyanomethane, chloroform, benzene and diethylether and partially soluble in warm DMF $\left(\sim 40^{\circ} \mathrm{C}\right)$. The insolubility is difficult to explain especially when it covers such large number of complexes. This fact inforce some limitation such as conductivity measurements in solution and ${ }^{1} \mathrm{H}-\mathrm{nmr}$ measurements, yet it was possible to deduce the proposed structure in a similar way to the dithiocarbamate complexes.

\section{References}

[1] S.J. Price, P.J.Sadler "Gold drugs in frontiers in bioinorganic chemistry", Xavier, A.V., (Ed), VC+1 Publ. Weinhein, pp376-388(1986).

[2] O.M.Dhubhghaill and P.J. Sadler "Gold complexes in chemotherapy in metal complexes in chemotherapy", B.K. keppler (Ed) VCH Publ. Weinhein, pp 225-250(1993).

[3] K.C.Dash and H.Schmidbar, "Metal ions in biological systems", H. Sigel, Ed., Marcel Dekker, New York, p.179ff(1982).

[4] C.F.Shaw," Progress in chemistry, biochemistry and technology", Schmidbau r, H., Ed., Wiley, New York, P.259ff(1999).

[5] P.J.Sadler and R.E.Sue, "The chemistry of gold drugs", B.K. Keppler (Ed) VCH Publ. Weinhein, PP 115-127(1994).

[6] V.Mariana "Structural studies of metal complexes with aminoacids and biomarkers for use in diagnostic", Ph.D thesis, Babes-Bolyai University, Romania,(2012) website www.ubbcluj.ro

[7] H.C.Freeman, "Metal complexes of aminoacids and peptides,inorganig biochemistry", Eichhorn,G.L.,Ed., Elsevier, Scientific, Amsterdam,(1),PP 121-166(1973).

[8] H.Hossain, M.S.Islam,A. Alam,T. Saltan,"Synthsis, physicochemical studies and antimicrobial screening of metal complexes of $\mathrm{Fe}(\mathrm{III})$ and $\mathrm{Au}(\mathrm{III})$ with aminoacids", Inter.J.Sci and Tech. Res.,2,7,(2013).

[9] N. Manav, A. K. Mishra and N.K. Kaushik," In vitroantitumour and antibacterial studies of some $\mathrm{Pt}(\mathrm{IV})$ dithiocarbamate complexes", Spectrochim Acta. Part A Molecular and Biomolecular spectroscopy, 65(1),32 (2005).

[10] G.Hogrth,"Metal dithiocarbamate complexes: chemistry and biological activity", Mini Rev. Med. Chem., 12(12), pp1202-1215(2012).

[11] K. Rajasekar,R.T. Ramchandramoorthy and A. Paulraj," Microwave assisted synthesis, structural characterization and biological activities of 4-aminoantipyrine and thiocyanate mixed ligand complexes", Res.J. Pharmaceutical Sci., 1(4), pp 22-27(2012).

[12] A. Vogel, "A text book of practical organic chemistry". ELBS: London, pp499-501(1968).

[13] F.F.Jian, Q.Hao, X.Hang,L.Lu,X.Wang, "Structure of bis $\left(0,0-\quad\right.$ diisopropyldithiophosphato-S, $\left.\mathrm{S}^{\prime}\right)(1,10-$ phenanthroline N1,N10) zinc(II) complex, [Zn(phen)(S2P(OiPr)2)2]", J.Chem.Crytallog. 30, 7, pp469472(2000).

[14] W.J. Geary, "The use of conductivity measurements in organic solvents for characterization of coordination compounds", Coord. Chem. Rev., 7, 81(1971).

[15] E.A. Abdalrazaq, N.H. Buttrus and A.A. Abd Al-Rahman, " Crenthecic and sharactorization of mold(iii) complexes with bis-(1,4-sodium thioglycolate) butane ligand", Asian J. Chem., 22, (3), pp 2179-2186 (2010).

[16] J.M. Tunney, A.J. Blake, E.S.Davies, J. Mcmater, C.Wilson and C.D. Garner, "Synthesis and structure of gold(III) complexes of asymmetric dithiolene ligands "Polyhedron., 25, 2,P. 591, (2006).

[17] A. Manohar, K. Ramalingam, and K. Karpagavel, "Mixed ligand complexes involving bis(dithiocarbamato)nickel(ii) and phosphorus donors: synthesis, spectral, thermal studies and bvs investigations" Inter.J. Chem.Tech. Res., 4, (4), pp1383-1391, (2012).

[18] A. J. Odola and J. A.O. Woods," Synthesis, characterization and antimicrobial activity studies of new nickel(ii) mixed ligand complexes of disubstituted dithiocarbamates with ethylsalicylaldiminate" Scholars Research Library, Archives of Applied Science Research, 3 (4)pp 463-470,(2011).

[19] L. Giovagnini, C. Marzano, F.Bettio and D.Fregona, "Mixed complexes of $\mathrm{Pt}(\mathrm{II})$ and $\mathrm{Pd}(\mathrm{II})$ with ethylsarcosinedithiocarbamate and 2-/3-picoline as antitumor agents", J. Inorg. Biochem. 99, (11), 21392150(2005).

[20] L. Szucova, Z. Travnicek and J. Marek," O,O Dialkyldithiophosphato and O-alkyldithiophosphato nickel(II) complexes with bidentate P-donor ligands", Polyhedron 22 pp 1341- 1348(2003).

[21] L.Bolundut, I. Haiduc, E. Ilyes, G KociokKhn, K. C. Molloy and S. G'mezRuiz, " Hydrogen bond supramolecular selfassembly in nickel(II) dithiophosphates, $\mathrm{Ni}\left[\mathrm{S}_{2} \mathrm{P}(\mathrm{OR})_{2}\right]_{2}, \mathrm{R}=$ sec- $\mathrm{Bu}$, iso- $\mathrm{Bu}$, and their bis(pyrazole) adducts", Inorg. Chim. Acta. 363, pp 4319-4323(2010).

[22] F. Jian, K. Jiao, Q.Wang and H.Wang, " Synthesis and crystal structure of trans-bis(o,odiisopropylthiophosphoryl-1Himidazole-N3)bis(o,odiisopropyldithiophosphato) nickel(II) complex: $\mathrm{Ni}\left[\mathrm{N}_{3} \mathrm{ImSP}(\mathrm{OiPr})_{2}\right]_{2}\left[\mathrm{~S}_{2} \mathrm{P}(\mathrm{OiPr})_{2}\right]_{2}(\mathrm{Im}=$ imidazole; iPr = isopropyl)", J. Chem. Crystallo., 34, (2), (2004). 
[23] A. K. Molodkin, N. Ya. Esina, O. I. Andreeva, and M. Konde, " Mixed-Ligand Platinum(IV) Complexes with amino acids and cytosine", Russi. J. Inorg. Chem., 53, (8), 1295-1303,(2008).

[24] M. B.Tarallo, A.J. C. Filho, E. D. Vieira, A.Monge, C.Q. Leite, F.R.Pavan, G. Borthagaray, D.Gambino, M. H. Torre, "Research of new mixed-chelate copper complexes with quinoxaline $\mathrm{N}_{1}, \mathrm{~N}_{4}$-dioxide derivatives and alanine as ligands, potential antimycobacterial agents".97,(1),80-89 (2009).
[25] A. Caubet, V. Moreno, E.Moins and C. Miravitiies," Methionine and histidine $\mathrm{Pd}(\mathrm{II})$ and $\mathrm{Pt}(\mathrm{II})$ complexes: crystal structures and spectroscopic properties"J. Inorg. Biochem., 48, 135-152 (1992).

[26] A. Iakovidis and N. Hadjiliadis," Complex compounds of platinum (II) and (IV) with amino acids, peptides and their derivatives", Coord. Chem. Rev., 135-136, P.17,(1994). 